KEYWORDS

Social classes

Social structure

Social mobility

Economic aspects

Political aspects

Social problems

Urban environment

Chile

Kathya Araujo

Professor, University of the

Academy of Christian Humanism

•karaujo@academia.cl

Danilo Martuccelli

Professor, Paris Descartes University

Centre for the Study of Social

Links (CERLIS)

National Centre for Scientific

Research (CNRS)

œ danilo.martuccelli@parisdescartes.fr
CEPAL REVIEW 103 APRIL 2011

\section{Positional inconsistency: a new concept in social stratification}

\author{
Kathya Araujo and Danilo Martuccelli
}

ased on empirical research involving some 100 semi-directive interviews with individuals from different social groups, this article introduces and discusses the use of a new concept for analysing the phenomenon of social stratification in contemporary Chilean society, namely "positional inconsistency". This describes a more or less permanent and generalized feeling of positional anxiety in the vast majority of social strata, which has specific characteristics that distinguish it from other similar processes (status fear, vulnerability, exclusion, mobility, for example). It is an experience which, although expressed in similar ways, is nonetheless fostered by a plurality of factors giving rise to a significant structural phenomenon. 


\section{I}

\section{Introduction}

This article develops the idea that the study of social stratification in Latin America needs to be extended to take account of an experience which, although not exclusive to the region, has specific and decisive characteristics in it. Based on data from Chile, the article will demonstrate the existence of an experience of "positional inconsistency", which is commonly occurring and cuts across different social strata.

The thesis is developed in four stages: section II briefly describes the analysis that links the growing complexity of social situations to the study of positional anxiety. Section III stresses the commonality of positional inconsistency in different social strata and then distinguishes it from other similar concepts. Section IV describes the various threats which, paradoxically, reflect both its cross-cutting nature and its diversity in the various sectors studied. Lastly, and by way of conclusion, the article mentions some of the day-to-day challenges that the experience of positional inconsistency poses in the life of most of the individuals interviewed.

This article is based on empirical research carried out in Chile (in the cities of Santiago, Concepción and Valparaíso) between 2007 and 2009, through some
100 semi-directive interviews with men and women of between 30 and 55 years of age, from low-income urban sectors and middle- and high-income groups. In general, the social sciences tend not to use qualitative methods to study social stratification. Most research in this field displays a statistical desire to aggregate individuals into a small number of groups (classes or strata) that define the positional architecture of a society. In Chile, there are numerous essays of this type, which, depending on the theoretical options chosen, emphasize the decisive importance of work, income, consumption, or culture (or a combination of these factors) when defining the boundaries of the major social positions. Statistical techniques are clearly essential when making classifications of this type. Nonetheless, this article aims to highlight a different phenomenon and draw attention to a subjective dimension that is relatively neglected in many studies of social stratification, strictly defined. Without denying the relevance of social divisions, in that dimension it will be necessary to recognize the presence of a common cross-cutting experience of positional inconsistency, underlying the diversity of social positions, as a major feature of social status in today's Chile.

\section{II}

\section{From social stratification to a cross-cutting positional experience}

Although attempts to find a schematic and more or less pyramidal view of major class positionings have not disappeared in Latin America, a more complex view of social positioning is steadily gaining ground. Even in studies that attempt to define the broad class positions in the continent based on the primacy of capitalist-type relations, a variety of other structural factors also need

This article reports some of the results of National Scientific and Technological Development Fund (FONDECYT) research project No.1085006, on subject individuation and configuration processes in contemporary Chilean society. The authors are grateful for the opinions offered by anonymous referees, and for comments and suggestions that have made it possible to enhance the first version of this article. to be invoked (Portes and Hoffman, 2007). In addition to the traditional coexistence of different modes of production (modern, small enterprise and others), there is a multiplicity of resources that give access to power, prestige or wealth -including both different forms of remuneration and different forms of work contract (and the different levels of social coverage and protection that these imply). The result is a growing awareness that it is essential to draw on a wide variety of factors to more precisely describe social stratification in Latin America. This progressively leads to tension between studies that define class dynamics, and those that adopt a more descriptive approach (Dubet and Martuccelli, 
2000). This is precisely the meaning of the important contrast between the six major social classes described by Portes and Hoffman (2007) and the 45 social categories distinguished by León and Martínez (2007) in their proposed classification of social actors in Chile.

This reflects a general trend towards increasing complexity of the actual heterogeneity of social situations, which thus far has occurred particularly in Latin America, giving renewed attention to other forms of capital or total assets. The employment-income-education triad has been augmented by a plurality of other factors, such as social capital, the nature of social networks, modes of belonging, different social stereotypes, the capacity to access and control the dominant cultural codes, the importance of places of residence (neighbourhoods), the fact of being a homeowner or not, the effect that personal and family life (separations, deaths and other events) have on social paths. There is also is the primordial role of consumption in the region, not only in the process of breaking down the barriers between social groups, but also in the appearance of new modes of symbolic inclusion among low-income sectors (García Canclini, 1995; Aguilar, 2009), such that, in Chile and elsewhere, a social stratification model generated from market studies has been imposed on public opinion, which classifies Chileans in the categories ABC1 (10\% - elite and upper middle class), C2 (20\% - middle middle class), C3 (25\% - lower middle class), D (35\% - poverty) and E (10\% extreme poverty) (Rasse, Salcedo and Pardo, 2009).

Although the idea of a positional pyramid persists in social stratification studies, awareness of the existence of a wide variety of intermediate positions is steadily consolidating. In other words, the multiplicity of the social positioning factors studied makes it increasingly hard to know who is truly "up" or "down", while hybrid positionings are increasingly common, and actors may simultaneously and contradictorily experience upward or downward mobility in different social domains. Moreover, this is true in most social strata. The traditional classbased division between groups - although still present in individual mindsets (Araujo, 2009) and evident in terms of income deciles - needs to be supplemented by the view of a continuum of social positions with no abrupt changes between them (AIM, 2000). This reality is partly reflected by the fact that between $60 \%$ and $80 \%$ of Chileans claim to belong to the "middle classes", which makes this social group predominant when defining the profile of current Chilean society (Torche and Wormald, 2007; León and Martínez, 2007).

Nonetheless, although in Chile the generalization of this sense of belonging to the middle class is important, one should not forget an essential characteristic, namely the marked dispersion and heterogeneity of social experiences observable in a given social group, whether in the low-income sector or in the so-called middle classes (Barozet and Espinoza, 2009), which calls for recognition of the increasing singularity of experiences within different social strata (Espinoza, 2002).

Despite the importance of this type of approach stressing the singularity of social positions, the research reported in this article reveals the existence of a crosscutting phenomenon in the vast majority of them. Except for a durable and globally protected elite, in a country characterized by high levels of concentration of various forms of power (Molina, 2005), most individuals feel their position is extremely permeable and susceptible to social deterioration. The widespread awareness of this situation defines one of the major positional characteristics of Chileans today: the sense that all positions are liable to suffer active destabilization processes.

\section{III}

\section{What is positional inconsistency?}

At the heart of this experience of positional inconsistency is the sense that anything can change at any time. It is a permanent positional worry, a daily anxiety that reflects a society wracked by multiple senses of instability. Positional inconsistency is a multiform concern, plural in its sources and generally constant, which gives rise to a climate of positional anxiety shared by many individuals in different social strata. To describe this experience more precisely, it is worth distinguishing it from other apparently similar notions, such as underclass or marginality; vulnerability or exclusion; status fear or status inconsistency; or social mobility.

(i) Despite the greater role accorded to urban or economic issues in certain testimonies, positional inconsistency is at the opposite extreme of studies of the underclass. The inconsistency in question does not exclusively concern economic change (the shift from an urban and industrial economy to a periurban 
economy dominated by services), or an essentially urban phenomenon (Wilson, 1987 and 1996). If one considers the experience of the outlying urban areas of Greater Santiago, no specific urban identity has been generated, and the positional inconsistency that its inhabitants complain about cannot be reduced merely to an economic process that has polarized the social structure on new foundations. On the contrary, it is as citizens, generally engaged in the labour market and sharing the mainstream criteria and values of Chilean society, that these inhabitants express their discontent, frustration and positional inconsistency. The problem is not that they are unlike other people, but that by perceiving themselves collectively as others, they feel their positions are particularly unstable. Most of the inhabitants interviewed in these neighbourhoods, whatever their economic status, were formal workers (or had family members working in this sector). Accordingly, they are defined less by their exclusion or economic informality (low overall in Chile) than by their lack of skills and low incomes. The problem is not that they are "out". The problem is that because they are "in" they feel fragile.

It is in this sense that the notion of positional inconsistency differs from "marginality". The latter concept stresses a specific structural dimension, namely the limits of the capitalist system in the region, unlike in central countries, to absorb the excess supply of labour from the countryside (Nun, 1969; Quijano, 1971). The major characteristic of positional inconsistency relates not only to a small number of actors (who have been "forgotten" or "left behind" by progress), but to a numerically very large group that perceive their position through a sui generis sense of inconsistency.

(ii) Positional inconsistency denotes a broad social process that cuts across many social strata, although, as discussed below, the sources and its weight vary. Unlike some social stratification studies in which "vulnerability" (generally defined exclusively in relation to poverty) has been confined to the low-income sector and even to an informal proletariat (Contreras and others, 2005; Torche and Wormald, 2007), inconsistency defines a social experience pertaining to many other social strata. Certainly, some studies have shown how the lowincome world (sometimes referred to as "sector D") suffers from both potential and also chronic vulnerability. Despite this distinction, however, the key point, clearly revealed in the studies of the
Socioeconomic Characterization Survey (CASEN), is that vulnerability always denotes a socially welldefined experience (Ramos and others, 2004). Of course, the reasons for this restricted use of the notion are legitimate, but given the qualitative material that has been produced here, it seems essential to use a broader notion to designate the feeling of positional anxiety expressed by the vast majority of individuals.

A similar distinction applies to "exclusion". Here, although the term is highly polysemous, one can argue that what underlies this notion is a process of fragilization which increasingly affects social groups that are perfectly adapted to modern society but, nonetheless, are victims of economic circumstances and in particular the employment crisis. In this sense, exclusion is a concept which, without denying the existence of a "fourth world" or an extreme "poverty", focuses on more integrated social groups. Nonetheless, in this analytical extension, and despite the desire to provide a dynamic and multidimensional definition of exclusion, the core of the analysis prioritizes the thesis of the existence of a crisis of social relations, and relates, sooner or later, essentially to transformation of the modes of integration provided by employment (Castel, 1995; Paugam, 1996). This experience is very far from doing justice to the inherent characteristics of the labour market in Latin America and, in some countries, to the violence of the process through which class divisions are being broken down (Minujín, 1993).

(iii) Positional inconsistency can also not be reduced to mere "status fear" or to "status inconsistency", although it sometimes includes this process. Although aspects of this type of anxiety are sometimes present in positional inconsistency, the latter is nonetheless different. In the first case, anxiety occurs amidst social positions that are perceived as solid; it is the solidity of the places in question and difficulty in accessing and occupying them that gives rise to status anxiety, the need to fabricate a personality aimed at active and permanent defence of status, as has been magnificently established in relation to the courtesan or organization man (Elias, 1982; Whyte, 1957; Kocka, 1989; Boltanski, 1982). In contrast, in the case of positional inconsistency it is social position itself that is seen as porous and susceptible to deterioration.

In the second case, the notion shares with status inconsistency the characteristic of indicating a 
loss of status legibility, the fact that contradictions exist between the various (economic or symbolic) registers of a position; that hybrid positionings are increasingly common, and that actors may simultaneously experience contradictory movements up or down in different social domains - in most social strata. Nonetheless, while sharing these aspects, in the case of positional inconsistency, what is stressed is the blurring of positions occupied by actors and the associated sense of anxiety, rather than the contradictions.

The situation of the "middle classes" in Chile makes it possible to specify this distinction more precisely. This social group is characterized by a transition, insufficiently addressed by theory, in terms of its anxiety. For a long time, the specific anxiety of this social group, located in an intermediate position by definition, was considered in theoretical terms more in terms of status than position. Being middle-class meant, first and foremost, possessing and defending a social status (Portocarrero, 1998). In the last few decades a genuine transition has occurred. Without disappearing, the traditional status anxiety pertaining to the middle classes is crystallizing into a fear of "falling" (Ehrenreich, 1989); but above all it is yielding, surreptitiously, to a distinct sense of positional inconsistency. Although the terms used are sometimes similar, since both cases visualize the fear of dropping down the social scale, the essence of the processes are different. In the first case, anxiety originates from a desire to defend "privileges" or "rights", even access to a status (Lomnitz and Melnick, 1991). In the second case, it is a question of multiplying resources or support (economic, political or relational) to underpin and solidify a social position that is perceived as inconsistent, through a set of relational strategies, (Barozet, 2002; Sánchez, 2009). In the first case, it is the famous "decency" of the Latin American middle classes, and the symbolic frontiers that can be built around that, which defines the status boundary; in the second case, it is not a question of maintaining a given position, but of maintaining position per se. In fact what is involved here is maintaining oneself in a position which, given its unstable nature, needs to be underpinned by individual and collective strategies.

(iv) Lastly, the widespread sense of inconsistency in social positions cannot be reduced only to a direct effect of upward or downward social mobility, or entry into and exit from poverty. This analytical distinction is particularly important, since Chilean society in recent decades has displayed high rates of social mobility in a context of marked urban segmentation and accentuated income inequality (Torche, 2005; Contreras, D., O. Larrañaga and J. Litchfield, 2001). The mobility rate, measured in terms of the income distribution, is highly eloquent in the short run: between 1996 and 2006, just $18.9 \%$ of Chileans included in the study were still in their original income deciles 10 years later (Arzola and Castro, 2009, pp. 70-72). Moreover, this mobility, albeit in different proportions, can be discerned both in the poorest decile (over the 10 -year period, just $28.1 \%$ remained in this same position, which points to significant upward social mobility), and in the top decile (where just $45.4 \%$ remained in the same income decile and decade later). In other words, even if mobility is greater among the poorest sectors than in the wealthiest groups, it is significant in all cases.

Without doubt, this reality is consistent with the sense of positional inconsistency expressed by the interviewees. Nonetheless, the phenomenon here seems broader, not only, as shown below, because of the plurality of sources evoked, but also because members of the middle class, and particularly the upper-class, sectors interviewed here, displayed a profound positional anxiety, even though inter-generational mobility in Chile (the likelihood of moving from the lowest quintiles to the highest and vice versa) is low (Núñez and Miranda, 2009). This means that, although mobility between groups is high, at the upper end of the distribution Chilean society seems particularly closed to the circulation of elites, since various "closed-shop" mechanisms are deployed (Contardo, 2008). Nonetheless, and although at the top of the Chilean social "pyramid" there are barriers that seem unbreachable, this does not remove anxiety in relation to positional inconsistency among the members of this group.

In short, positional inconsistency describes a gradation of situations, because not all actors experience it with the same intensity; and, in particular, not all experience it in terms of the same factors. This inconsistency differs widely according to historical periods and, obviously, between social strata; but it also differs in terms of the factors that are taken into account. The traditional pairing of economy and social relations needs to be augmented by other political, cultural, and urban factors, to restore the complexity of this experience. 


\section{IV \\ The differentiated generalization of positional inconsistency}

Positional inconsistency thus denotes a specific experience - a simultaneous mix of status and process. Status: the sense of inconsistency is constant among actors, despite the prosperity they may display in many respects. Process: inconsistency, even when it adopts abrupt forms, is always the result of a series of phases that steadily weaken or deteriorate a given position. To understand this dual reality and its differentiated generalization in current Chilean society, it is useful to distinguish four major factors.

\section{Socioeconomic destabilizations}

In structural terms, since the 1980s the Chilean economy has gone through a major transformation involving the shrinking of agricultural sectors, the far reaching changes in manual work (accompanied by a substantial reduction in manual labour and a significant internal transformation of this group), and the outsourcing of jobs that has gone hand-in-hand with growth of the private sector and the decline of public employment. This transformation has generally meant that employment has lost its protection capacities, accentuating the trend towards more precarious conditions in the occupational structure, although the phenomenon in Chile is more complex and less uni-directional than often claimed. The transformation process involves both "improvement" and "deterioration" simultaneously — probably not unrelated to the appearance of spurious forms of social mobility, such as individuals who become entrepreneurs and express nostalgia for their former manual worker status, or trades-people who yearn for their former life in agriculture (Kessler and Espinoza, 2007, p. 285). One can thus hypothesize that what underlies these attitudes is a vague awareness of an increase, despite the "objective" mobility experienced, or the feeling of growing positional inconsistency.

This sentiment, as the interviews presented below demonstrate and regardless of how frequently it appears among individuals from different social groups, reflects very different conditions depending on whether the individual in question works in the formal or informal sector of the economy (Infante and Sunkel, 2004), whether he or she has one or more incomes, and also on the type of employment contract. Nonetheless, there is variety not only in what underlies the anxiety, but also in how it takes the form of chronic worry, or not, and how it is dealt with. Curiously, it is not individuals who display greater "objective" fragility who necessarily express the greatest positional anxiety. What seems to be common and cross-cutting in the interviews, however, is a widespread perception of never definitively or lastingly feeling protected from economic destabilization. This inconsistency can be shown by a large number of factors.

\section{(a) The spectre of job loss}

In Chile, unemployment has a huge effect on the likelihood of being poor or slipping back into poverty (Arzola and Castro, 2009). But, beyond the figures, and even the effective diversity of protection and indemnification mechanisms that different wage-earners enjoy, what needs to be stressed is the type of awareness that individuals express in relation to this eventuality. A perception of more or less acute social exposure, a feeling of more or less pronounced impotence: "It's a very perverse, very cruel system; the law doesn't support you, it doesn't protect you; there's no safety net. In my case, unemployment insurance lasted three months..." (male, executive). This fear, which is intensified by age and its consequences for job opportunities was often called to mind: "Here, once past 40 you're too old for work" (male, 49); "In this country, if you're over 40, you're old and expensive; so I may now be very expensive for my firm; they could pay two or three people with my wage, and sometimes this worries me..." (male, 51) "As we get older we encounter more competition every day and it's harder to get ahead, which generates a type of anxiety" (male, 44).

\section{(b) Bankruptcy}

If wage earners are afraid of losing their jobs, entrepreneurs and self-employed workers fear bankruptcy. Of course, negative experiences should not eclipse the successful experience of many others (or the same people at different times in their lives). Nonetheless, there is a common anxiety among this group. In fact, 
their situation is paradoxical. In the last few decades, the income of independent workers in Chile has grown faster than that of wage earners, such that in 1987-1995, average income grew by $90 \%$ in the non-wage categories (entrepreneurs and own-account workers), compared to just $45 \%$ among wage-earners (León and Martínez, 2007 , pp. 316 and 321). In contrast, however, and as a continuation of one of the broad characteristics of this type of work, there is a permanent sense of anxiety and lack of protection. Their position depends, ahead of many other things, on the buoyancy of the market; and any market contraction generally has direct consequences for their income level: "What happens is that you lose your long-term perspective, you get into difficulties and every time you get up in the morning your concern is to get to the end of the day ... you let yourself be swept along and you lose objectivity. People talk to you, but you don't reply, you become emotionally involved..." (male, entrepreneur)

\section{(c) Market fluctuations}

The anxiety of positional inconsistency can be clearly seen in the awareness displayed by the interviewees in identifying links between global economic changes and their personal situations. In some cases, for example, it is opening up to the international market that clearly marks the change in their life. An example is this woman, who runs a shoe shop and whose life-line was cut "when Chinese shoes started to enter the market". The experience of another middle-class woman is somewhat different. She had to start working: "When things started to turn bad in my husband's factory... my husband has an industrial tapestry factory and when the floodgates were opened to allow so many Chinese products in, we were done for." It is worth considering this point in more detail. The important thing is not the plausibility of the interpretations put forward (an area widely studied by economists through the effective and regional propagation of economic crises, for example (Daher, 2004)); what is important to focus on is the strength of this cultural repertoire in the perception of social position itself.

\section{(d) Debt}

While indebtedness worries many social groups, this experience was directly mentioned by half of the individuals interviewed; and nearly three times as many people referring to this experience belonged to lowincome groups. Clearly, in this difference, one needs to take account of the greater or lesser facility with which members of certain social groups are prepared to describe their economic difficulties to strangers. Nonetheless, it is reasonable to postulate that this is a particularly significant experience in low-income sectors, because, in those sectors, the threshold of positional disequilibrium is crossed more quickly. On this point, apart from its apparent similarity, two broad mechanisms are described in the testimonies. Firstly, what can be described as "slippage" — the almost permanent feeling that given monetary shortcomings and lack of saving or social protection, it is possible to slip into a situation of overborrowing at any time and in the face of any adversity. Secondly, a mechanism in which the most important aspect of the story is indebtedness resulting from an unstoppable chain of events, as if the wheels of the mechanism, once in motion, are impossible to halt, and the "machine" becomes an implacable schemer: "We were deep in debt because my husband had an accident and was off work for three months. And the bills keep coming in and everything you earn is used to pay the expenses of the house, to have enough to eat, but the bills keep accumulating... Well, you have to try and tighten your belt a bit more to be able to pay, first of all the electricity and water which are basic expenses... but what you owe to the shops also keeps growing..." (female, paper recycler).

\section{(e) Turbulence, slides and switchbacks}

Lastly, although this is not an exhaustive listing, there is another type of experience which, in its broader version we will discuss below. What does this refer to? As a result of positional inconsistency, regardless of its association with a socioeconomic event (job loss, bankruptcy, current circumstances or indebtedness), a range of social experiences is created through which these events represent a transitory turbulence ("We still live in excellent apartment, but my parents had to bring food to the house because we didn't have money to buy food..." (male, engineer); a long slide (in other words a marked process of downward social mobility or entry into poverty); or a switchback: a phase of rapid descent followed by a generally slower stage of recovery of social position. In sociological studies, these situations are generally evaluated through statistical techniques, to measure how long it takes people who "fall" to "rise up again". These analyses are clearly very valuable, because the impact of the fall (into poverty) depends on how long it lasts. But they at least partly minimize an issue that is particularly highlighted in these testimonies: namely, that these "rises" or "falls" are affirmed and articulated in the widespread and constant perception of positional inconsistency. 


\section{Political fears}

In terms of the influence of politics on Chilean society, in 1973 and 1989-90, and even the at time of the interviews in 2007-2009, and the possibility of a political change occurring in 2010 (with the victory of the Alliance), seem a source of positional inconsistency, albeit with clearly different intensities and even as an imaginary anxiety. This widespread experience of anxiety has been described, using other theoretical assumptions, as a set of "fears" that are inherent in current Chilean society (UNDP, 1998 and 2002).

Obviously, this sentiment has deep historical roots. But the fear expressed in relation to politics cannot be seen as a continuity: it is no longer collective, in the historical form of a fear of widespread disorder (although this is not entirely absent); but it is more personalized, the highly individual feeling that politics adds to the long list of factors that can destabilize a situation or social path (Tironi, 2009, p. 92).

This point is crucial. Firstly, because it seems a counterintuitive empirical result, since it calls into question what has been considered as evidence: a society marked by continuity and a weakening of the political factor owing to the adherence by the main government coalitions to common patterns of economic management. This reading echoes the thesis that the impact of political changes in the ordinary social life of people worldwide has decreased significantly. Nonetheless, the results described here emphasize that this thesis needs to be downplayed in the Chilean case. Political change is seen by many individuals as an almost direct source of positional destabilization. An engineer expressed this view clearly: "I believe political change is important because it affects your personal life, your family, work... whatever. For example, a short while ago with all the announcements that were being made, it turns out that company profits were recalculated and share values fell... in that sense it affects you". Or as a courier says: "I don't like politics, but we're involved in politics, you can't stand aside from it because it's everywhere".

This fear of the effects of politics on ordinary life is very strongly rooted in the memory of the dictatorship. "It was very difficult, it was a very very hard time, because you saw things you'd never seen before... bayonets, tanks, soldiers in the street, ... low-flying aircraft ...All of this marks you, it has an impact on you..." (female, paramedic). In fact, the testimonies and the fear expressed display very similar features, and in fact there is a remarkable narrative standardization: military presence, abuse, rumours, among other things. The vast majority of those interviewed had very specific memories of that September 11. The feeling of widespread fear even among those who supported the military regime: " $M y$ mother told us: 'Be very careful girls if you ever see a new chevy, there were some cars like that with blacked out windows and men with moustaches, if you see that, keep out of the way because one day they may grab you, bundle you into the car, and we'll never see you again...' - 'But why?' - 'Because they are the security forces and just as they grab communists and socialists, they may come across a girl they like the look of and force her..." (female, journalist).

This political fear was clearly an active agent of inconsistency, also expressed through the very practical and material consequences that this event had socially and economically as a factor of family impoverishment, for example. It was also an active agent, but in the opposite direction, among supporters of the dictatorship: "When my father lost his job at Codelco" this lawyer recalls "and the economy started to become more liberalized, you had to be prepared for that, and my father was not prepared... he came from a culture, let's say, that you had to be employed, and to switch to a way of life that requires other tools, was extremely difficult". Others, with a similar rationale, recalled how the military coup psychologically destabilized one of their parents or threw them into long-term unemployment: "When I was born, my father was unemployed and marked by the military ... my father was eight years at home, eight years unable to find a job...".

Politics as a factor of positional inconsistency was also invoked by those who describe themselves as supporters of the dictatorship: "The Unidad Popular is what most marked my life because for three years we went to bed with a gun by our side ... three years ... this was in the countryside. They were always breaking into kill... and they killed all of our neighbours, who were families like us, they killed all of them ... they broke in and they killed them ... People from the Unidad Popular and the MIR they killed them. People have forgotten that, but I saw whole families killed ... they took over the property and they killed them". This lawyer has no hesitation in stating that the Unidad Popular period was "the most horrible, most hateful period, the greatest hate that I have seen in my life was in that period." In many cases, the impact is such that it recalls the experience evoked in the previous paragraph on the switchback, in which people who lost their job, got it back, or others saw their situation get worse and then improve rapidly.

This effect is not confined to these experiences but is continuous throughout these decades. A producer 
recalls, for example, that her participation in one of the publicity spots for the NO campaign in 1989, had economic consequences for her, because a client who recognized her changed firm. And during the interviews held between 2008 and 2009, a large percentage of the people interviewed were actively afraid of change in political majority. Our empirical material thus shows a widespread fear, and positional anxiety is one of its most lasting expressions. Something that seems so simple and so profound in its consequences, in the testimonies of the interviewees, is the fact that in Chile, to reuse the words of one of our interviewees, politics affects personal life, the family and work, because politics is everywhere.

\section{Dangers and urban threats}

The third source of positional inconsistency is one of the main markers of the social distance between individuals in Chile today. While the fear of urban perils is by no means absent among middle-income groups, it is very much in evidence among low-income sectors and particularly among women from those sectors.

Firstly, the city of Santiago has a social morphology marked by pronounced social polarization and residential segregation. The social geography between the classes is well reflected and inscribed in the city: in the three wealthiest boroughs, for example, poverty affects less than $2 \%$ of the population, compared to almost $40 \%$ among residents of the poorest boroughs (De Mattos, 2004, p. 28). Alternatively, one can point to the fact that the highest-income people live in just 6 of the 34 boroughs of the metropolitan region, and the poorest in just 20 (Rodríguez and Winchester, 2004, p. 116). This division has led to some analysts highlighting the relevance of the "two cities" hypothesis, in which the rich and poor areas of Santiago are mutually independent ( $41 \%$ of the city's boroughs are socially homogeneous).

Secondly, these statistical conglomerates conceal a high degree of fragmentation of situations and experiences at the local level and within neighbourhoods. In short, the undeniable urban polarization of Santiago conceals a myriad of social micro-fractures, which are particularly visible among the lower-income sectors. In the so-called C strata, but particularly in D, there is a high level of internal heterogeneity. Living standards in some cases approach those of the extreme poverty sectors, whereas others are close to lower middle-class standards (Rasse, Salcedo and Pardo, 2009, p. 21). In other words, lowincome housing conceals very heterogeneous realities depending on whether one lives in a residential area (villa) or a shanty town, and whether or not one lives in a neighbourhood whose reputation, or the value of the house acquired or being acquired, has deteriorated), not forgetting, of course, the insecurity experienced in the urban area.

Nonetheless, it is mainly within the low-income neighbourhoods, in those segregated spaces with high levels of inequality terms of quality of public services, that the feeling is expressed that the city is a major source of positional threat. Four large narrative modes are repeated and overlap in the accounts given.

First mode: "One's own" neighbourhood, although not great, is not as bad as the others. This attitude is seen also in many other places, and testifies not only to the importance of micro-segregation strategies within population groups or low-income neighbourhoods, but also to one of the key features of the rationale of comparison between urban inhabitants. Here, the reference group with which individuals compare themselves always includes people who live in "worse" neighbourhoods. Why? Because, whatever the state of deterioration, is impossible for individuals not to perceive that their neighbourhood is where they live their lives. The essential effort to maintain dignity leads to this differentiation: "The neighbourhood (Quilicura) is peaceful, where I live it's very peaceful. Although I live almost at the entry to the barrio, there's another part which is very bad, but it's further in, but I found this place here which is more peaceful" (female, cleaner) "Well, our zone is very peaceful, because we're all working people", but "yes, there are problems, but on the other side of the neighbourhood, that's where there are bad people, ... there are more juvenile delinquents further in. At least here, it's very peaceful, it's really good" (female, paper recycler).

Second mode: The arrival of what many of the people interviewed referred to as the "new folk", and with them, in a chain of causality that the narration establishes as evidence, an increase in theft and other types of crime that make it always necessary to be on the alert, to be watchful: "Here everyone knows everyone else in the zone, which consists of about 120 apartments, so we know each other, and suddenly people from outside arrive, who we often don't know, and that's changed the neighbourhood" (female, cook). Now, who are these "others"? Where do they come from? Does this not reveal an underclass within low-income sectors? In short, is there greater social and cultural difference between one group and the others, or not? Used with caution, the material presented here provides answers to some of these questions. While some of these "other people", the new arrivals, may be part of the most 
recent waves of migration to the city of Santiago and, according to some studies, come from rural areas, they are generally very similar socially to the "old" inhabitants. In essence, this is the universe - well analysed by Norbert Elias- of the configuration between the "established" and the "outsiders" (Elias and Scotson, 1965). As in his famous study, here too the existence or otherwise of real differences between one or other group is of little importance. What matters is that the difference in time of residency generates contrary sentiments in the two groups, because inevitably, as the testimonies collected clearly exemplify, the older or "established" inhabitants perceive the new ones, to use the language of Elias, as "outsiders", as a multiform threat to the urban control they have exercised until then.

Third mode: Drugs as a territorial-exogenous type of alarm. In this register, the repeated reference to drugs in the discourse of the inhabitants, particularly among women from low-income sectors, reveals a positional fear that is expressed in a specifically maternal way: that their children may be tempted into drug use, become involved in drug trafficking, and end up as victims of the violence that this produces in neighbourhoods. Drug trafficking generates a specific form of positional anxiety: "Until about two years ago the borough of $L a$ Cisterna was excellent, very peaceful, great to live there, you could go out at night and nothing ever happened, but now everything has gone to ruin because of drugs, gangs ... Partly because of the people that came from outside and set up their evil business and start to lead our young astray, so much so that there have been suicides, murders, a horrible situation ... Just two months ago we buried a young lad who grew up with my daughters..." (female, market salesperson). This housewife who lives in another neighbourhood tells a similar story: "The neighbourhood has changed because a lot of drugs are circulating, and children join gangs ...violence, there's a lot of theft, so that's what's changed...".

Fourth mode: Move somewhere else. If "move somewhere else" seems the inevitable conclusion of the foregoing narratives, it is far from being a practical possibility for everyone. Firstly, because even though there maybe an enormous desire, not everyone has the possibility to imagine (still less implement) a solution of this type. Nonetheless, according to a survey, in 2001, $65 \%$ of the inhabitants of very low cost housing units in poor boroughs want to leave their social housing (quoted in Dammert and Oviedo, 2004, pp. 281 and 282). Yet the impossibility of doing so, as shown by the interviewees, leads to a feeling of entrapment and urban resignation "I just pray to God to let me sell the house where I live, move to another neighbourhood that's a little bit better ... All I want now, for example, is to leave the area I live in (the borough of El Bosque), because when I arrived here it wasn't like this ... it has changed..." states this domestic employee. Secondly, because, despite their fears, not everyone can leave the neighbourhood, for urban ties are real and deep rooted in some cases. What remains then is collective action with its possibilities and limitations, the affirmation of the urban space as a way of manifesting their rights in it.

Although this subsection has highlighted the experience of women from low-income sectors, the aim is to underline the specific nature of this modality of positional inconsistency. Naturally, concern for theft and even urban insecurity is present also among the middleand higher-income groups, but the fear is concentrated in the socioeconomically more vulnerable sectors, as also are complaints of delinquency and crime (Dammert and Oviedo, 2004). When urban insecurity manifests itself among the middle- and high-income groups, this experience is not merely specific but a factor of positional inconsistency in itself. In contrast, in low-income sectors, particularly among women, insecurity, when it appears, immediately generates another experience, which is clearly more anxiety-provoking, namely the fear of seeing one's social position temporarily or permanently destabilized by socio-urban changes.

\section{The unstoppable logic of "accidents"}

The final source of destabilization to be mentioned is less homogeneous than the previous ones, yet its heterogeneity is what gives rise to its profound unity. This is a set of dissimilar factors, generally presented and recounted as "accidents of life", which disturb a path, a life project or a social position. Having said that, clearly all human life is subject to unforeseeable events; contingency, and the events that occur in life, indelibly mark our existence. Nonetheless, not all of them have the capacity perceived by actors, whether real or imagined, to change a life course or put it seriously at risk. What basically defines this logic of accidents is the importance given to them and the narrative role they end up possessing in the description of the paths.

Although different in each case, these "accidents" have been massively recorded by women in low-income sectors (nearly all of them used this narrative form), compared to less than a quarter of men and women from middle- and high-income groups, and nearly half of men interviewed from low-income sectors. Often, accidents are presented as specific experiences that destabilize, but 
fail to dramatically change the course of life. On other occasions, events of this type ultimately proved highly significant in terms of their positional consequences. The "accident" becomes a "catastrophe". Theft, for example, will have more or less definitive consequences, such as the case of a woman from a low-income sector who, by losing her papers in the event, will be evicted from her house because she is unable to prove her property title. Undesired pregnancies that precipitate marital or conjugal unions, mostly between men and women from low-income sectors; or falling into drug abuse which compromises the whole family path.

A further point can be made here: life everywhere is marked by tragic accidents; but not only do they have different repercussions according to the social groups in question, they are also more or less absorbed according to the social positions that the individuals in question hold. The more resources available to them, the fewer are the "immediate" repercussions on those positions that suffer existential tragedies. On the contrary, as revealed by the testimonies collected, in Chile today the tragic vicissitudes of existence often translate into positional destabilization.

The list is long and varied. In some cases it was intra-family sexual violence that triggered a long and fractured process of social deviation or family conflict. In other cases, it was an experience of depression or another illness which, owing to the costs generated, put not only intra-family solidarity to the test, but also its capacity to cope with debts that became chronic: "I've got debts from five years back, because of cancer; I took on a debt that I can't pay; I've renegotiated it five times, and from 250,000 pesos it now has grown to a million..." (male, salesperson).

These experiences are really existential, and what draws attention to them are their consequences in terms of positional inconsistency. Does it need to be said? These experiences are never confined to this aspect and, without doubt, it is not necessarily this facet that is emphasized in the stories compiled. Endless pain and interminable grief, the sense of a life brought to an abrupt halt, or a wound that will never heal, form part of this reality.

\section{V}

\section{From positional inconsistency to individuals}

In Chilean society, this experience of positional inconsistency, which cuts across many social strata, is all the more significant when the country has experienced high rates of economic growth in recent decades, which have translated, despite the persistence of social inequalities, into a clear sense of improvement and prosperity (Ffrench Davis, 2008). This sentiment is revealed, for example, in the national surveys undertaken for the Human Development Report published by the United Nations Development Programme (UNDP) between 1998 and 2008, which globally reflect the fact that individuals perceive that their personal situation unequivocally improved over the last few decades (Güell, 2009). In short, Chilean society has experienced a process of collective enrichment which has translated into a perception, held by a majority of Chileans (up to $60 \%$ ), that their living standards are better or much better than those of their parents (Torche and Wormald, 2007, p. 355).

Without denying this, in conclusion it is worth considering what this multiform anxiety reveals about Chilean society. Schematizing the results, it may be said that positional inconsistency is massive among low- income sectors and generally relates to economic and urban factors, but also reflects the destabilizing effects of existential "accidents". It is worth noting that politics is a less important factor in this sector. In contrast, in the medium-high income groups, the main reasons for inconsistency stem from political and economic anxieties, and also, albeit to a lesser extent, from fears related to "accidents", whereas the urban dimension is particularly absent. Despite these differences, however, this study reaches a key conclusion: as regards social stratification, it needs to be recognized that behind the plurality of places, in Chile today there is a shared paradoxical feeling of positional inconsistency.

In this plural anxiety one can discern the presence of a particular variant of the individualization process (Beck, 1998; Bauman, 2003), in which individuals sense that they have to actively cope with a set of issues, which, in other societies, or even in Chilean society in other times, were the responsibility of institutions or structurally assured by the fact of belonging to a given social stratum (Araujo, 2009). In this sense, this article considers that studies on social stratification should 
pay special attention to positional inconsistency; not only because this reality, despite the heterogeneity of its sources, introduces a cross-cutting interpretation between strata, but also because it can be found in the origin of many other phenomena present in the country - starting, for example, with the excessive demand for protection that individuals direct towards the family, and which is probably not unrelated to some of their current difficulties (Valenzuela, Tironi and Scully, 2006). There is also a need to develop strategies of favour and reciprocity networks, to alleviate this positional anxiety, generating a sort of "alternative functional system" (Robles, 2000), or setting up strategies within social practices that have an inclusive and structuring function (Barozet, 2006).

For individuals, the reality of positional inconsistency has twin consequences. Firstly, it induces actors to form social networks to protect themselves from risks.
Secondly, given the awareness that these have their limits, owing to the structural, plural and permanent nature of inconsistency, the feeling (in reality the philosophy) that you have to get by in life on your own, gains strength. In Chile, individuals are perceived as being obliged to seek their own responses to a series of structural failures, which inevitably increase insecurities and differences between actors; a feeling that, ultimately, whatever the unequivocal weight of economic processes, life cannot simply be reduced to this single dimension. Positional stability which yesterday was transmitted by ancestry or surname, by middle-class "decency", and for others by certain forms of wage and community protection, is now increasingly seen as a globally inconsistent reality that constantly requires the deployment of necessarily personal, family and social strategies. Consequently, positional inconsistency is a structural phenomenon of prime importance in contemporary Chilean society.

(Original: Spanish)

Bibliography

Aguilar, O. (2009), "Principios de diferenciación material y simbólica en la estratificación social", El arte de clasificar a los chilenos, A. Joignant and P. Güell (coords.), Santiago, Chile, Ediciones UDP. AIM (Asociación Chilena de Empresas de Investigación de Mercado) (2000), Metodología de medición de niveles socioeconómicos. Método utilizado por AIM Chile [online] http://www.aimchile. $\mathrm{cl} / \mathrm{G} 1$.asp

Araujo, K. (2009), Habitar lo social, Santiago, Chile, Lom Ediciones. Arzola, M.E. and R. Castro (2009), "Determinantes de la movilidad de la pobreza en Chile (1996-2006)", El arte de clasificar a los chilenos, A. Joignant and P. Güell (coords.), Santiago, Chile, Ediciones UDP.

Barozet, E. (2006), "El valor histórico del pituto: clase media, integración y su diferenciación social en Chile", Revista de sociología, No. 20, Santiago, Chile, Faculty of Social Sciences, University of Chile.

(2002), L'échange de faveurs au sein des couches moyennes chiliennes: de l'entraide informelle à la régulation sociale, thesis, École des hautes études en sciences sociales (EHEss).

Barozet, E. and V. Espinoza (2009), “¿De qué hablamos cuando decimos "clase media"? Perspectivas sobre el caso chileno", El arte de clasificar a los chilenos, A. Joignant and P. Güell (coords.), Santiago, Chile, Ediciones UDP.

Bauman, Z. (2003), Modernidad líquida, Buenos Aires, Fondo de Cultura Económica.

Beck, U. (1998), La sociedad del riesgo, Barcelona, Paidós.

Boltanski, L. (1982), Les cadres, Paris, Minuit.

Castel, R. (1995), Les métamorphoses de la question sociale, Paris, Fayard.

Contardo, O. (2008), Siútico, Santiago, Chile, Vergara.

Contreras, D., O. Larrañaga and J. Litchfield (2001), "Poverty and income distribution in Chile 1987-1998: new evidence",
Cuadernos de economía, vol. 38, No. 114, Santiago, Chile, Catholic University of Chile.

Contreras, D. and others (2005), "Movilidad y vulnerabilidad en Chile", Foco, No. 56, Santiago, Chile, Expansiva.

Daher, A. (2004), "Riesgo-país versus riesgo-región: Santiago en el MERCOSUR", Santiago en la globalización: ¿una nueva ciudad?, C. de Mattos and others, Santiago, Chile, Ediciones Sur.

Dammert, L. and E. Oviedo (2004), "Santiago: delitos y violencia urbana en una ciudad segregada", Santiago en la globalización: ¿una nueva ciudad?, C. de Mattos and others, Santiago, Chile, Ediciones Sur.

De Mattos, C.A. (2004), "Santiago, Chile: metamorfosis bajo un nuevo impulso de modernización capitalista", Santiago en la globalización: ¿una nueva ciudad?, C. de Mattos and others, Santiago, Chile, Ediciones Sur-Eure libro.

Dubet, F. and D. Martuccelli (2000), ¿En qué sociedad vivimos?, Buenos Aires, Losada.

Ehrenreich, B. (1989), Fear of Falling, New York, Pantheon Books.

Elias, N. (1982), La sociedad cortesana, Mexico City, Fondo de Cultura Económica.

Elias, N. and J. Scotson (1965), The Established and the Outsiders, London, Sage.

Espinoza, V. (2002), "La movilidad ocupacional en el Cono Sur. Acerca de las raíces estructurales de la desigualdad social", Proposiciones, No. 34, Santiago, Chile, Ediciones Sur-Eure libro.

Ffrench Davis, R. (2008), Chile entre el neoliberalismo y el crecimiento con equidad, Santiago, Chile, J.C. Sáez Editor.

García Canclini, N. (1995), Consumidores y ciudadanos, Mexico City, Grijalbo.

Güell, P. (2009), "En Chile el futuro se hizo pasado: ¿y ahora cuál futuro?", El Chile que viene. De dónde venimos, dónde estamos y a dónde vamos, Santiago, Chile, Ediciones UDP. 
Infante, R. and G. Sunkel (2004), Chile: trabajo decente y calidad de vida familiar, 1990-2004, Santiago, Chile, International Labour Organization (ILO).

Kessler, G. and V. Espinoza (2007), "Movilidad social y trayectorias ocupacionales en Buenos Aires. Continuidades, rupturas y paradojas”, Estratificación y movilidad social en América Latina, R. Franco, A. León and R. Atria (coords.), Santiago, Chile, Lom Ediciones.

Kocka, J. (1989), Les employés en Allemagne (1860-1980), Paris, École des hautes études en sciences sociales (EHESS).

León, A. and J. Martínez (2007), "La estratificación social en Chile hacia fines del siglo XX, Estratificación y movilidad social en América Latina, R. Franco, A. León and R. Atria (coords.), Santiago, Chile, LOM Ediciones

Lomnitz, L. and A. Melnick (1991), Chile's Middle Class. A Struggle in the Face of Neoliberalism, London, Lynne Rienner Publishers.

Minujín, A. (1993), Cuesta abajo, Buenos Aires, UnICEF/Losada.

Molina, S. (2005), Es el tiempo de la equidad, Santiago, Chile, Academia Chilena de Ciencias Sociales, Políticas y Morales/ Instituto de Chile/Banco del Desarrollo.

Nun, J. (1969), "Superpoblación relativa, ejército industrial de reserva y masa marginal", Revista latinoamericana de sociología, vol. 2, Buenos Aires.

Núñez, J. and L. Miranda (2009), "La movilidad intergeneracional del ingreso y la educación en Chile", El arte de clasificar a los chilenos, A. Joignant and P. Güell (coords), Santiago, Chile, Ediciones UDP.

Paugam, S. (1996), L'exclusion: l'état des savoirs, Paris, La Découverte.

Portes, A. and K. Hoffman (2007), "Las estructuras de clase en América Latina: composición y cambios en la época neoliberal", Estratificación y movilidad social en América Latina, R. Franco, A. León and R. Atria (coords.), Santiago, Chile, Lom Ediciones.

Portocarrero, G. (comp.) (1998), Las clases medias: entre la pretensión y la incertidumbre, Lima, Sur-Oxfam.

Quijano, A. (1971), Redefinición de la dependencia y proceso de marginalización en América Latina, Santiago, Chile, Latin
American and Caribbean Institute for Economic and Social Planning (ILPES).

Ramos, J. and others (2004), Cómo ha cambiado la vida de los chilenos, Santiago, Chile, National Institute of Statistics (INE).

Rasse, A., R. Salcedo and J. Pardo (2009), “Transformaciones económicas y socioculturales: ¿cómo segmentar a los chilenos hoy?", El arte de clasificar a los chilenos, A. Joignant and P. Güell (coords), Santiago, Chile, Ediciones UDP.

Robles, F. (2000), El desaliento inesperado de la modernidad, Santiago, Chile, RIL Editores.

Rodríguez, A. and L. Winchester (2004), "Santiago, Chile: una ciudad fragmentada”, Santiago en la globalización: ¿una nueva ciudad?, C. de Mattos and others, Santiago, Chile, Ediciones Sur-Eure libro.

Sánchez, J.F. (2009), Las estrategias relacionales de las clases medias en Cali-Colombia, Brussels, Catholic University of Louvain.

Tironi, E. (2009) "Identidad y relatos nacionales", El Chile que viene. De dónde venimos, dónde estamos y a dónde vamos, Santiago, Chile, Ediciones UDP.

Torche, F. (2005), "Unequal but fluid social mobility in Chile in comparative perspective", American Sociological Review, vol. 70, No. 3, Nashville, Tennessee, American Sociological Association.

Torche, F. and G. Wormald (2007), "Chile, entre la adscripción y el logro", Estratificación y movilidad social en América Latina, R. Franco, A. León and R. Atria (coords.), Santiago, Chile, LOM Ediciones.

UNDP (United Nations Development Programme) (2002), Nosotros los chilenos: un desafio cultural, Santiago, Chile.

(1998), Las paradojas de la modernización, Santiago, Chile.

Valenzuela, J.S., E. Tironi and T.R. Scully (eds.) (2006), El eslabón perdido, Santiago, Chile, Taurus Editores.

Wilson, W.J. (1996), Jobless Ghetto, New York, Knopf. (1987), The Truly Disadvantaged, Chicago, University of Chicago Press.

Whyte, W.H. Jr. (1957), The Organization Man, New York, Doubleday Anchor Books. 